\title{
Article
}

\section{Dairy Farm Management Information Systems}

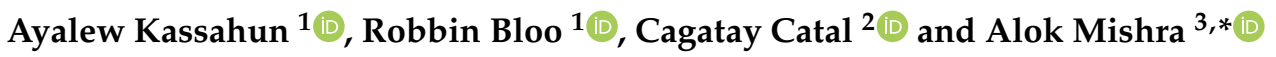 \\ 1 Information Technology Group, Wageningen University \& Research, 6706 KN Wageningen, The Netherlands; \\ ayalew.kassahun@wur.nl (A.K.); robbin.bloo@wur.nl (R.B.) \\ 2 Department of Computer Science and Engineering, Qatar University, Doha 2713, Qatar; ccatal@qu.edu.qa \\ 3 Faculty of Logistics, Molde University College-Specialized University in Logistics, 6410 Molde, Norway \\ * Correspondence: alok.mishra@himolde.no
}

check for updates

Citation: Kassahun, A.; Bloo, R.; Catal, C.; Mishra, A. Dairy Farm Management Information Systems. Electronics 2022, 11, 239. https:// doi.org/10.3390/electronics11020239

Academic Editors: Juan Antonio Martinez Navarro, José Santa and Andrés Muñoz

Received: 11 December 2021

Accepted: 10 January 2022

Published: 12 January 2022

Publisher's Note: MDPI stays neutral with regard to jurisdictional claims in published maps and institutional affiliations.

Copyright: (C) 2022 by the authors. Licensee MDPI, Basel, Switzerland. This article is an open access article distributed under the terms and conditions of the Creative Commons Attribution (CC BY) license (https:// creativecommons.org/licenses/by/ $4.0 /)$.

\begin{abstract}
Nowadays, different types of farm management information systems (FMIS) are being used in practice in several sectors of farming, such as dairy, arable, fruits, vegetables, and meat farming. The goal of this research is to identify, evaluate, and synthesize existing FMISs in the Dutch dairy sector and present the state-of-the-art. We performed a multivocal literature review (MLR) to find sources both in scientific and grey literature. A grey literature search was adopted because most of the FMISs were not reported in the scientific literature. To support and improve the effectiveness of the MLR process, an online survey was first sent to Dutch dairy farmers to identify the FMISs that are being used in practice. With the help of the MLR process, we identified 50 FMISs used by Dutch dairy farmers. We identified 33 features of these FMISs and listed the advantages and disadvantages of the FMISs.
\end{abstract}

Keywords: grey literature; multivocal literature review; precision agriculture; smart agriculture; smart systems

\section{Introduction}

Many businesses use specific software systems that provide modules for their particular sector. Therefore, many software vendors offer domain-specific software solutions. To this end, extensive industry knowledge is required to be able to develop software solutions. In order to advance the state-of-the-art and build robust software solutions for a given sector of the industry, quite substantial research in information systems is being conducted per sector.

An example of such a domain-specific information systems research can be found in the agricultural sector, particularly research on Farm Management Information Systems (FMISs) [1-3]. As farms increasingly become automated and data-driven, farmers adopt modern FMISs [4,5]. With the development of new technologies such as sensors on farm equipment, more and more data are becoming available and providing many new possibilities in managing farms. For instance, data-driven farm management leads to a reduction in costs, an increase in the quality of products, improves animal welfare, and increases safety in general.

A specific example considered in this research is the dairy sector. In this sector, the two prominent software-intensive developments are the use of milking robots and activity monitors. A milking robot keeps track of milk yield and calculates the percentages of fat and protein content in the milk [6]. The data generated by the milking robot are generally managed by an on-premises or cloud software system that is connected to the milking robot. The software system provides the farmer with a dashboard that shows the values of various attributes about each individual cow and the milk the cow produces. This allows the farmer to identify deviations from normal production levels and the health of the animal. An activity monitor attached to cows, such as a step counter, keeps track of the activities of each individual cow [7]. The activities of cows are stored either in a software 
system provided by the solution provider, which may be located at the farm or in a cloud computing platform. Such systems provide the farmer with useful information about the cows, such as lameness and the right moment of heat.

FMISs such as those provided with milking robots and activity monitors are distinct from standard herd management FMISs, such as the AgroVision system (available online: https: / /www.agrovision.com/dairy / (accessed on 2 June 2021)). In order to synthesize the data and derive useful information, the farmer is forced to combine data from the different FMIS systems manually. For instance, when data from the milking robot indicates lower milk production, the farmers need to manually combine information from the system associated with the step counter with information from the standard herd management FMIS in order to diagnose the loss of productivity.

There are diverse FMISs for managing dairy farms. However, it is unknown yet to what extent the current FMISs support the required features to manage the entire processes in dairy farms. The assessment of the functionalities of FMISs reported in a recent study [3] indicates that the current FMISs support only a small part of the information needed on the dairy farm. However, only a fraction of the available FMISs used in practice is reported in the scientific literature and thus many of FMISs used in practice were not covered by recent studies such as that conducted by Tummers et al. [3]. Consequently, it is unknown which FMISs are used in practice by dairy farmers, and which features they support. The FMIS market in the Dutch dairy sector is also highly fragmented, and it is not well known which FMISs are used, and to what extent they support the entire dairy farm management process.

The goal of this research is to identify and synthesize existing FMISs and their features for dairy farms by searching scientific publications and the grey literature. In this study, we focused on the Dutch dairy sector. We applied a multivocal literature review (MLR) methodology [8] together with an online survey study [9] approach that enhanced the validity of the MLR and there by closing the gap between practitioners and academia on a study of management information systems. We applied the questionnaire-driven approach in order to identify the most relevant FMISs; thus, this MLR study differs significantly from traditional MLR studies and other related work. In that perspective, the main contributions of this study are fourfold:

1. This study presented FMISs used in the Dutch dairy sector and their main features using the MLR methodology, which is different from the systematic literature review (SLR) methodology [10] that is widely used in past studies.

2. Thanks to the approach that combined online survey questionnaire with the analysis of both grey and white literature on the subject, this study identified the most relevant features, advantages, and disadvantages of FMISs.

3. Using both the survey study and MLR approaches this study showed the different types of data managed by the different types FMIS systems. The data types identified include fertility values, cow activity, rumination activity, concentrate feed intake, calving dates, milk yield, quality attributes (fat percentage, protein percentage, cell count, LDH percentage, BHB percentage, conductivity), fertilizer use, field location, field area, bull characteristics, feed intake, and money flows.

4. We observed that technologies that are, or can be, used in combination with the FMIS systems are not clearly mentioned in the grey literature (websites and product documentation of FMISs) reviewed. Cognitive technologies such as machine learning, computer vision, robotics, natural language processing (NLP) and speech analysis have huge potential in the context of FMISs. While conventional FMISs use traditional mathematical equations for different prediction tasks, new FMISs increasingly apply machine learning techniques and more recently, deep learning approaches. However, these technologies are not explained explicitly in the documentations of the available FMISs. This study shows the need for more research on these technologies and the need for informing farmers about the technologies utilized in these FMISs.

The following sections are organized as follows: Section 2 presents the background and related work. Section 3 explains the methodology and the MLR process. Section 4 
shows the results of the study. Section 5 presents the discussion, and Section 6 presents the conclusion.

\section{Background and Related Work}

The following three subsections present the concepts used in this study, which are FMIS, SLR, and MLR.

\subsection{Farm Management Information Systems (FMIS)}

An FMIS is a management information system (MIS) that is used in the agricultural sector. An MIS is a software system for organizing and providing past, present, and projected information. The information includes both the internal operation of the organization and its interaction with the outside world [11]. An FMIS performs a similar task for the agricultural sector. According to Tummers et al. [3], an FMIS is defined as a system used for collecting, processing, storing, and disseminating information for carrying out the operations in the farming business. An FMIS collects data from all over the farm and provides the data in an informative manner to the farmer. The farmer is able to make better decisions by using an FMIS because the FMIS provides the farmer with better insights he/she would not have without the use of that FMIS. In the dairy sector, the farmer can, for example, receive health updates about his cows using an FMIS, and based on that fact he can change the supply of minerals to the cows. Such an update on the health of the cows might provide the farmer with the information he would not have had by simply checking the cows visually. The concept of the FMIS is applicable all over the agricultural sector. FMISs can, for example, be found not only in the domain of arable farming but also in the domain of greenhouse farming and orchard farming. An FMIS in dairy farming is obviously very different from an FMIS in other farming sectors. To this end, this research only focuses on FMISs that are specifically developed for use in the dairy sector.

\subsection{Systematic Literature Review (SLR)}

In order to understand the current state of scientific research in a specific subject, researchers apply a systematic literature review (SLR) protocol to identify, evaluate, and synthesize previous scientific articles on a particular subject. An SLR is a rigorous review of all research that is performed on a specific topic. To ensure that an SLR comes up with the desired results, the search for literature is based on keywords that describe the main focus of the research. The results that are retrieved using the keywords are thereafter put through different selection criteria. These criteria ensure that only the relevant studies are selected for further processing. In addition to the application of study selection criteria, quality assessment is also carried out to ensure the qualities of the identified papers. Different questions are answered for each paper (e.g., eight questions in total), and the total value based on the responses (yes $=1$; no $=0$; partial $=0.5$ ) determines the quality of the papers. For instance, the value four can be a threshold value for a question set, including eight questions.

\subsection{Multivocal Literature Review (MLR)}

According to the Luxembourg definition of grey literature, grey literature is "produced on all levels of government, academics, business and industry in print and electronic formats, but which is not controlled by commercial publishers, i.e., where publishing is not the primary activity of the producing body" [12]. This means that grey literature includes all forms of literature. One benefit of the grey literature search is that it enables us to find information on research topics that received little attention from the scientific research community.

An MLR is a combination of grey literature review and SLR. Garousi et al. [9] identified different levels of literature in software engineering, as depicted in Figure 1. First-tier grey literature is considered to have credibility due to high outlet control. Publications in this category include books, magazines, government reports, and white papers. Second- 
tier grey literature is considered moderately credible due to the moderate level of outlet control. Examples of publications in this category are annual reports and wiki articles. The remaining publication constitutes the third-tier publication and is considered to be the least credible. Examples of publications in this category are blogs, e-mails, and tweets.

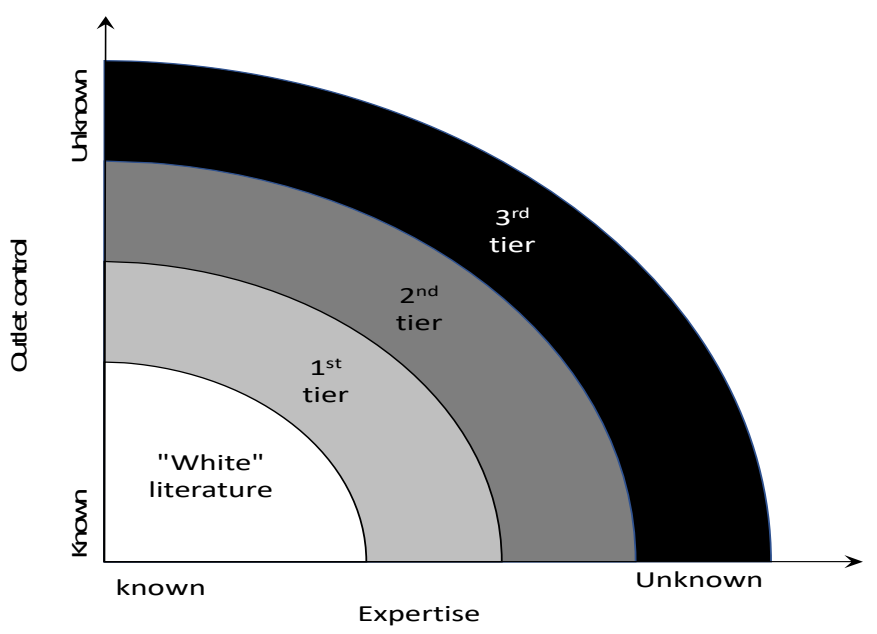

Figure 1. Different types of literature used in software engineering; adapted from Garousi et al. [9].

\section{Methodology}

The main research question (RQ) of this study is described as follows:

- Which FMISs are available for supporting dairy farms in the Netherlands, and what are their features?

This research question is further divided into five sub research questions listed as follows:

- RQ1: What are the current FMISs used in dairy farming?

- RQ2: What are the features of these FMISs?

- RQ3: What are the advantages and disadvantages of the current FMISs?

- RQ4: Which features do farmers lack in these FMISs?

- $\quad$ RQ5: What kinds of data are collected and managed by the FMISs?

In this research, we applied an MLR methodology in combination with an online survey study to address these questions. An MLR consists of a white and a grey literature review. White literature reviews, formally referred to as SLR, are applied to summarize the findings in the scientific literature. Grey literature review is a review of publications that are considered nonscientific because either the expertise of the authors, the outlet control (the review process), or both do not meet scientific standards. A survey study allows the researchers to capture the behaviors and attitudes of the research subjects and thus was used to identify to what extent the different FMIS systems were relevant in practice. The online survey (see Appendix A) was conducted first. This allowed us to identify the FMISs that are actually used in practice in the Netherlands. Then, an MLR was conducted to retrieve detailed information about the FMISs identified by the survey study. The results of this study are presented per each research question. The detailed methodology of this research is explained using four subsections: research setup, survey study, the MLR, and the mapping of the RQs into one of the three research methods.

\subsection{Research Setup}

The main research question that is formulated in the Introduction section is answered in this research by following the approach depicted in Figure 2. 


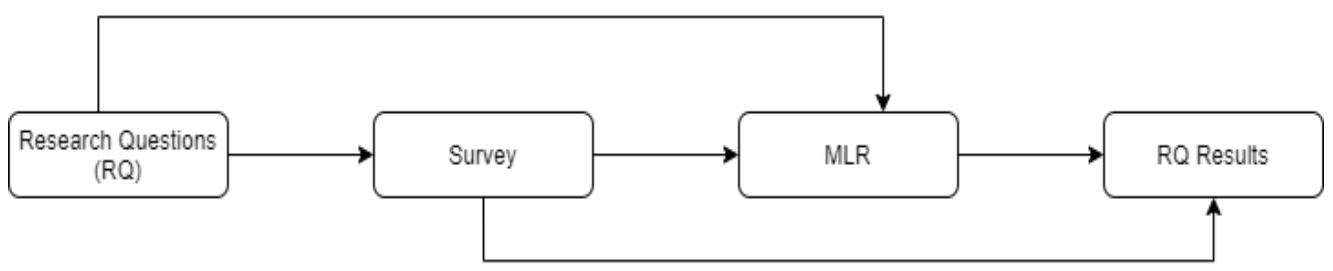

Figure 2. Research methodology.

- RQs and Survey. First, based on the research questions, an online survey questionnaire form was prepared. The questionnaire was then sent to dairy farmers. The answers provided by these dairy farmers were used to respond to the relevant research questions.

- $\quad$ MLR. The answers to the survey provided a good starting point for the MLR. Using the responses from the survey, company websites of FMIS providers and product review articles were identified, and more information about the FMIS was retrieved.

- $\quad R Q$ Results. These grey and white articles were thereafter used to discover new FMISs that were not previously mentioned by the farmers [13]. The way the survey was used in this research is, therefore, unique; the survey is not only used to answer the RQs directly but also is used to answer them indirectly via MLR.

- Another route followed in the scheme presented in Figure 2 is moving directly from the RQs to the MLR in order to answer some of the RQs. In this approach, we used the FMIS review webpage of Capterra (Available online: www.capterra.com/farmmanagement-software/ (accessed on 2 June 2021)) and Google search engine for the MLR study. The results of the MLR, together with the results of the survey, provided all the answers to the RQs. Section 3.4 depicts which research question is answered through which research method.

\subsection{Survey}

A survey is a research instrument for answering research questions by gathering information from a large number of respondents [14]. As such, a survey is a suitable way to retrieve information from the farmers to answer the research questions of this study. The survey addresses all research questions directly or indirectly, as described in Section 3.4. The survey questions are reformulations of the research questions in a manner that the respondents, who are dairy farmers, can understand. While the research questions refer to the general state of FMIS in use, the survey questions focus on the individual dairy farmer's knowledge, perception, and experience. To ensure a correct response, the term FMIS and the purpose of this survey were explained with a short introductory text.

In this research, an online survey was prepared using the online survey tool Qualtrics. To ensure that the farmers interpret the survey as we understand, a draft version of the survey was sent to three dairy farmers in the Netherlands. These dairy farmers provided feedback on the survey questions, which were later used to improve the questionnaire. The English translation of the survey questionnaire is included in the Appendix A, and the Dutch version of the survey was sent to the farmers. The survey was shared with dairy farmers through a Dutch Facebook group called "Koeien" (the Dutch word for "Cows") consisting of almost 30,000 members. A lot of these members are either dairy farmers or interested in dairy farming.

The survey was sent to members of the Facebook group called "Koeien". From this group, 32 farmers answered the survey questions. Out of the 32 farmers, 17 of them have never used any FMIS. Though the response rate of people who know about the FMISs was quite low, the survey provided very useful ideas and was a good starting point for our MLR study. The responses provided by the farmers were used to answer our research questions.

\section{3. $M L R$}

In order to keep a higher level of credibility, this research focuses not only on grey literature but also on white literature. The websites of FMIS developers were consulted first. 
A company website is considered first-tier grey literature because the company has the highest level of expertise about its own product, and the product specifications mentioned on the website can be considered as trustworthy. Grey literature from the second or third tier was used as a starting point for further research.

SLR. The white literature part of the MLR was retrieved from the Science Direct database using the following search key: TITLE-ABS-KEY (("Farm Management Information System" OR FMIS OR "farm management tools" OR" information systems") AND (dairy OR cattle OR cow)). Science Direct was selected for SLR because this database covers the most influential dairy-related journals.

We searched the literature from the last ten years, and this search resulted in 41 articles. The articles were selected by reading the title and abstract. The following criteria were used in the selection:

- $\quad$ The paper must be on the FMIS.

- $\quad$ The paper must concern the dairy cow sector.

- $\quad$ The paper must be in English or Dutch.

- The full text of the paper must be available.

The first two selection criteria ensured that only relevant articles about FMIS for dairy farming were selected. The third and fourth selection criteria were added because the researchers of this study can only fully comprehend scientific literature written in Dutch and English languages, and the full text is required to get the relevant information. The application of the selection criteria resulted in the selection of fifteen papers, which were read in full and analyzed in detail.

Grey literature review. Three sources were used for the grey literature research: the results of the survey, the Capterra FMIS registry, and the Google search engine. The grey literature research via the survey used the survey as a starting point. This means that the FMISs mentioned by the farmers served are used to access more online sources. The results from the survey helped to identify the name of several FMIS. Using the Google search engine, the relevant product website was identified and visited. Google search provided more information about the FMIS and links to other FMISs, such as those of the competitors or partners. This method of research is similar to the use of snowballing.

The second option for the grey literature search is using the Capterra software product registry. Capterra is a website that provides software product reviews. The FMISs retrieved in Captera were checked to see if they support dairy farming. Those FMISs that were selected were then used for further grey literature search.

The third option used was a brief search on Google for FMISs. This search contained the following search terms: "farm management system", "farm management information system" and "boerderij management systeem", which is a Dutch phrase that means "farm management system" in English. This search resulted in several company websites and journal articles.

\subsection{Mapping Methods to RQs}

The first subquestion (RQ1) is answered using the survey. This survey contains two relevant questions, which are listed as follows:

- $\quad$ Do you use one or more FMIS?

- Do you know any other existing FMISs that you do not use?

These questions in the survey resulted in an overview of the FMISs that are currently being used and known by the farmers who filled in the survey form. The MLR was then used to enhance the answer to RQ1 because the MLR enabled the identification of new FMISs that were not mentioned by the farmers.

The second subquestion (RQ2) is answered using MLR and the survey form. In the survey, the following two questions were asked to answer RQ2:

- What are the features of the FMIS you use?

- What are the features of the FMIS you know are also existing? 
The MLR was used to find more information about the mentioned FMISs. The third subquestion (RQ3) focuses on the opinion of the FMIS users; therefore, this subquestion is only answered by using the survey forms. In the survey form, the following two questions were asked to answer RQ3:

- What are the advantages and disadvantages of the FMIS that you are using?

- Why don't you use the other FMIS that you have heard?

The fourth research question (RQ4) is answered using the survey form since this question only relies on the opinion of the farmers. In the survey, the following question was asked to answer RQ4:

- Do you miss a feature on the FMIS that you are using, if so which feature(s) are missing?

The fifth research question (RQ5) is answered using MLR and the survey form. MLR comes up with technical reports about the FMISs, and the survey provides information about data used by the FMISs. A summary of the methods per research question is shown in Table 1.

Table 1. Summary of methods used to answer research questions.

\begin{tabular}{cccccc}
\hline & \multicolumn{5}{c}{ Research Questions } \\
\cline { 2 - 6 } & RQ1 & RQ2 & RQ3 & RQ4 & RQ5 \\
\hline MLR & $X$ & $X$ & & $X$ & $X$ \\
Survey & $X$ & $X$ & $X$ & $X$ \\
\hline
\end{tabular}

\section{Results}

In this section, we first analyze the responses to each question of the survey. We then present the analysis of the MLR.

\subsection{FMISs in Dairy Farming}

This section answers RQ1, which is about the current FMISs used in dairy farming.

\subsubsection{Survey Results}

The farmers were asked if they use one or more FMISs, and out of the 32 farmers who responded to this question, 15 farmers have used one or more FMISs (see Figure 3).

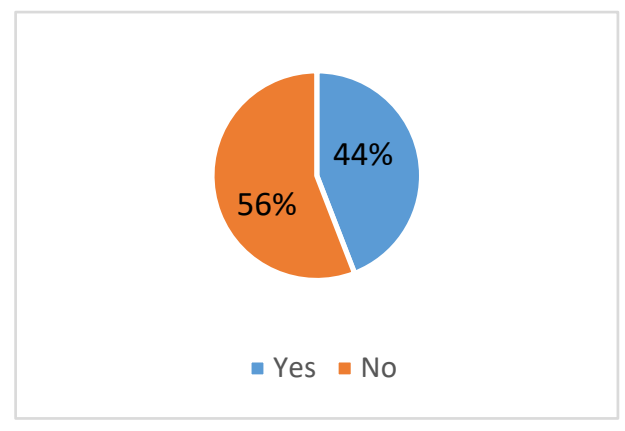

Figure 3. The proportion of farmers using one or more FMIS.

The farmers were then asked which FMISs they use. Figure 4 shows the FMISs used by the 15 farmers. The total number of FMISs exceeds 15 because many of the farmers use more than one FMIS. The survey results also showed that nine out of the 15 farmers who use one or more FMISs use an FMIS provided by the supplier of the milking robot, often together with a generic FMIS. Common combinations of FMISs are Lely T4C being used together with CRV Veemanager, and Delaval Herd Manager being used together with CowVision from AgroVision. 


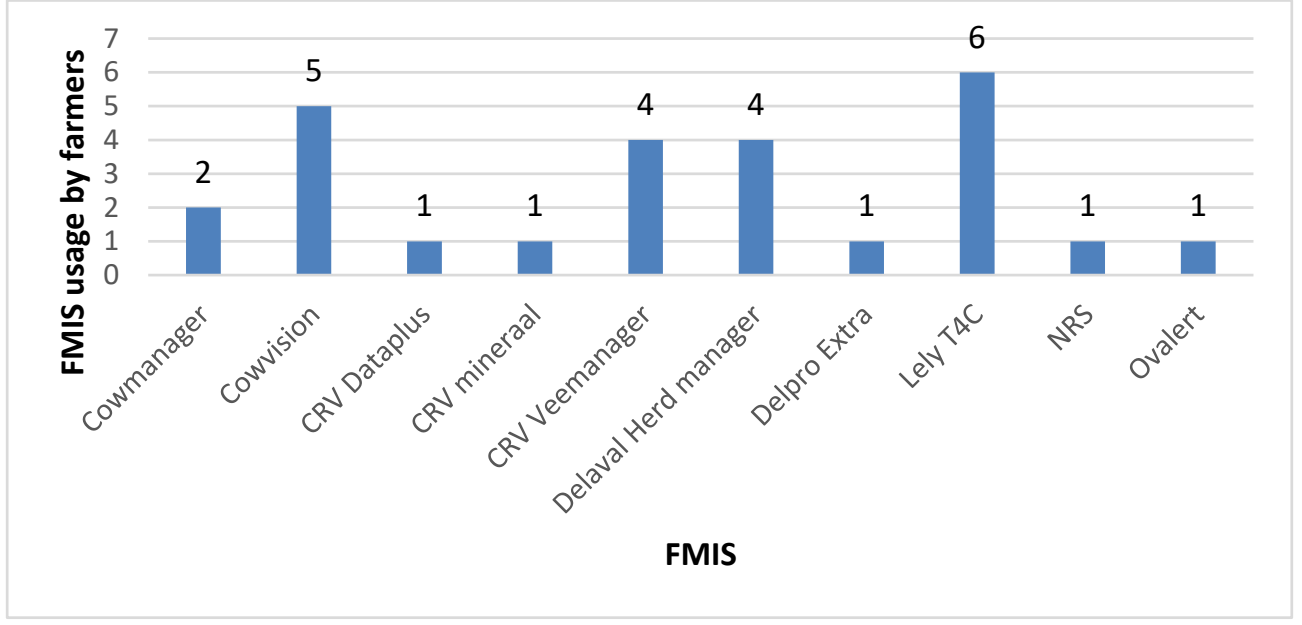

Figure 4. The use of different FMIS by the farmers $(n=15)$.

\subsubsection{MLR Results}

Table 2 shows different fields of the focus of the dairy FMISs. Table 3 shows the FMISs discovered through MLR. The first and second columns of Table 3 show the product name of the FMIS and which company provides that FMIS. The third column of Table 3 shows the field of focus of the corresponding FMIS, and the last column shows how the FMIS is discovered. Eight fields of focus were identified, which are defined in Table 2, together with a short description of the specific field of focus. How often the fields of focus occur in Table 3 are depicted in Figure 5.

Table 2. The different fields of the focus of the dairy FMISs.

\begin{tabular}{ll}
\hline \multicolumn{1}{c}{ Field of Focus } & \multicolumn{1}{c}{ Description } \\
\hline Data exchange & $\begin{array}{l}\text { This FMIS focuses solely on the exchange of data between multiple } \\
\text { other systems. It can also be seen as a data hub for the dairy sector. } \\
\text { This FMIS provides the farmer with information about his field. } \\
\text { This can, for example, be field size or location, but also information } \\
\text { about yield per specified area or about the percentage of phosphate } \\
\text { in the ground. }\end{array}$ \\
This FMIS provides the farmer with the tools he needs for his \\
financial management. This FMIS can, for example, keep track of \\
the income, the expenses, or the depreciation.
\end{tabular}


Table 3. An overview of the retrieved FMISs in this research.

\begin{tabular}{|c|c|c|c|}
\hline FMIS & Company & Field of Focus & Approach \\
\hline Merck Animal Health & Agdata & Livestock & MLR, via Capterra \\
\hline Agrimap & Agrimap & Field management & MLR \\
\hline Agrivi & Agrivi & Field, financial and livestock management & MLR \\
\hline Farmwizard Milk Manager & AgriWebb & Livestock and product management & MLR, via Capterra \\
\hline Cowvision & Agrovision & Field, financial and livestock management & survey, MLR \\
\hline Agri Tracking Systems & ATS & Field management & MLR \\
\hline BCS Cowdition & Bayer HealthCare & Livestock management & MLR \\
\hline Care4Cattle & Bayer HealthCare & Livestock management & MLR \\
\hline Boer\&Bunder & Boer\&Bunder & Field management & MLR \\
\hline SmartDairy & BouMatic & Livestock and product management & MLR \\
\hline Cowmanager & CowManager & Livestock and product management & survey, MLR \\
\hline Veemanager & CRV & Livestock & survey, MLR \\
\hline Ovalert & CRV & Livestock & survey, MLR \\
\hline Dataplus & CRV & Livestock and product management & survey, MLR \\
\hline CRV mineraal & CRV & Mineral/food management & survey, MLR \\
\hline Dacom & Dacom & Livestock & MLR \\
\hline DairyTuner & DairyTuner & Livestock and mineral/food management & MLR \\
\hline Dairy Compass & De Heus Voeders & Financial and product management & MLR \\
\hline DelPro & Delaval & Livestock and product management & MLR \\
\hline Herd manager & Delaval & Livestock and product management & survey, MLR \\
\hline DKE agrirouter platform & DKE-Data GmbH & Data exchange & MLR \\
\hline Droogstand op Maat & Duurzame & Livestock management & MLR \\
\hline EasyFarm 8.1-lite/plus & Easyfarm & Financial & MLR, via Capterra \\
\hline EasyFarm 8.1 pro Livestock & Easyfarm & Livestock & MLR, via Capterra \\
\hline EasyFarm 8.1-Premier & Easyfarm & Livestock & MLR, via Capterra \\
\hline EZ-Ranch & EZ-Ranch & Livestock & MLR, via Capterra \\
\hline Farm Matters Software & Farm Matters & Livestock & MLR, via Capterra \\
\hline Farmbrite & Farmbrite & Financial and livestock & MLR, via Capterra \\
\hline FarmERP & FarmERP & Field and financial management & MLR \\
\hline FarmLogs & FarmLogs & Field management & MLR \\
\hline $\mathrm{M}^{2}$ erlin & Fullwoord Packo & Product management & MLR \\
\hline CowView & GEA & Livestock management & MLR \\
\hline DairyPlan C21 & GEA & Livestock and product management & MLR \\
\hline IDA Management & Hoogland BV & Livestock management & MLR \\
\hline I Agri & I Agri Software & Field, financial, livestock and weather & MLR, via Capterra \\
\hline JoinData & JoinData & Data exchange & MLR \\
\hline T4C InHerd & Lely & Livestock and product management & MLR \\
\hline Meteor & Lely & Livestock management & MLR \\
\hline Cow Locator & Lely & Livestock management & MLR \\
\hline iCalve & Meyer Cattle Inc. & Livestock management & MLR \\
\hline MS Korund & MS Schippers & Livestock management & MLR \\
\hline COWControl & Nedap & Livestock, mineral/food and product mng. & MLR \\
\hline NRS & NRS & Studbook & Survey, MLR \\
\hline Bedrijven Kompas & Rabobank & Financial management & MLR \\
\hline Management Dairy Solution & SAC & Livestock and product management & MLR \\
\hline Farm Management Pro & Smartfarmsoftware & Field management, financial and livestock & MLR \\
\hline Trimble & Trimble & Field management & MLR \\
\hline NutriOpt & Trouw Nutriotion & Financial and mineral/food management & MLR \\
\hline UNIFORM-Agri & UNIFORM-Agri B.V & $\begin{array}{l}\text { Data exchange, financial, livestock and } \\
\text { product management, studbook }\end{array}$ & MLR \\
\hline KoeMonitor & ZuivelNL & Livestock and product management & MLR \\
\hline
\end{tabular}




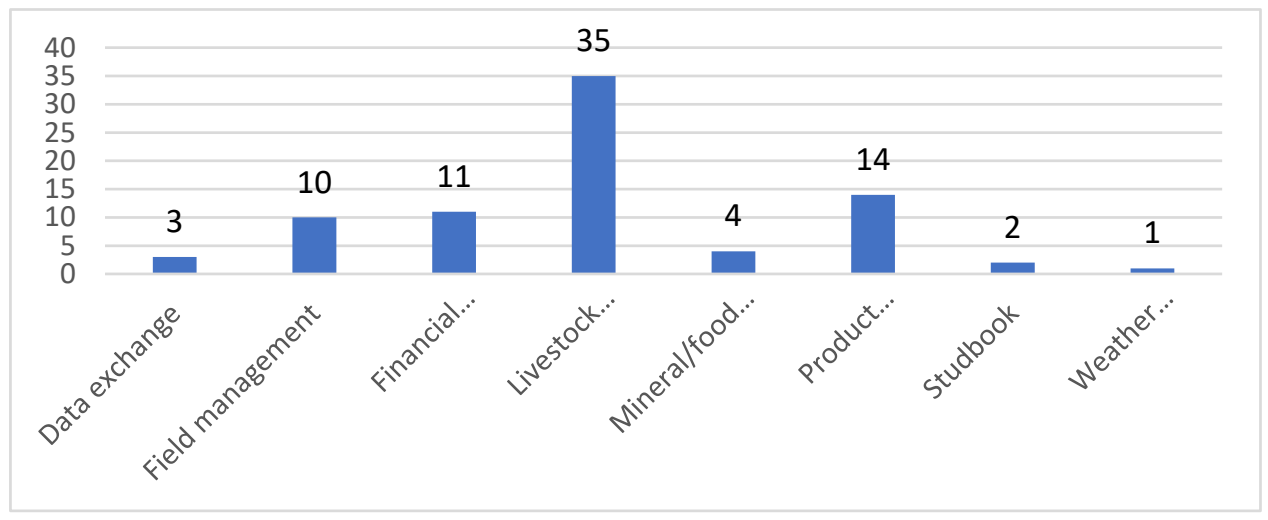

Figure 5. The number of times a field of focus of an FMIS is concerned by an FMIS.

Table 4 shows the codes of the specified fields of focus for an FMIS. The SLR resulted in 15 papers, which can be seen in Table 5. The table also shows the fields of the focus of the paper. The explanation of these fields is presented in Table 2. The number of times a reviewed paper concerned a certain field of focus of an FMIS can be seen in Figure 6.

Table 4. Codes for the specified fields of focus for an FMIS.

\begin{tabular}{cc}
\hline Code & Field of Focus \\
\hline F1 & Data exchange \\
F2 & Field management \\
F3 & Financial management \\
F4 & Livestock management \\
F5 & Mineral/food management \\
F6 & Product management \\
F7 & Studbook \\
F8 & Weather management \\
\hline
\end{tabular}

Table 5. Studies that were used to answer research question 1, together with their field of focus.

\begin{tabular}{|c|c|c|c|c|c|c|c|c|c|c|}
\hline \multirow{2}{*}{ Study Title } & \multirow{2}{*}{ Objective } & \multirow{2}{*}{$\begin{array}{l}\text { Authors } \\
\text { and Year }\end{array}$} & \multicolumn{8}{|c|}{ Field of Focus } \\
\hline & & & F1 & F2 & F3 & F4 & F5 & F6 & F7 & F8 \\
\hline $\begin{array}{l}\text { Spatial variation of soil nutrients in a } \\
\text { dairy farm and its implications for } \\
\text { site-specific fertilizer application }\end{array}$ & $\begin{array}{l}\text { Design site-specific } \\
\text { fertilizer } \\
\text { application maps. }\end{array}$ & $\begin{array}{l}\text { Fu et al. } \\
\text { [15] }\end{array}$ & & $X$ & & & & & & \\
\hline $\begin{array}{c}\text { Foraging paths through vegetation } \\
\text { patches for beef cattle in } \\
\text { seminatural pastures }\end{array}$ & $\begin{array}{l}\text { Investigate diet } \\
\text { selection in complex } \\
\text { swards }\end{array}$ & $\begin{array}{l}\text { Orr et al. } \\
\text { [16] }\end{array}$ & & $X$ & & $X$ & & & & \\
\hline $\begin{array}{l}\text { Integration of geospatial and cattle } \\
\text { nutrition information to estimate } \\
\text { paddock grazing capacity in Northern } \\
\text { US prairie }\end{array}$ & $\begin{array}{l}\text { Estimate short-term } \\
\text { grazing capacity for } \\
\text { small paddocks }\end{array}$ & $\begin{array}{l}\text { Phillips } \\
\text { et al. [17] }\end{array}$ & & $X$ & & & & & & \\
\hline $\begin{array}{c}\text { Management priorities of livestock } \\
\text { farmers: A ranking system to } \\
\text { support advice }\end{array}$ & $\begin{array}{l}\text { Investigate the } \\
\text { importance farmers } \\
\text { give to a variety of } \\
\text { tasks }\end{array}$ & $\begin{array}{l}\text { Mugnier } \\
\text { et al. [18] }\end{array}$ & & & $X$ & $X$ & $X$ & $X$ & $X$ & \\
\hline $\begin{array}{l}\text { Development of automatic body } \\
\text { condition scoring using a low-cost } \\
\text { 3-dimensional Kinect camera }\end{array}$ & $\begin{array}{l}\text { Estimate dairy } \\
\text { cows' energy } \\
\text { reserves }\end{array}$ & $\begin{array}{l}\text { Spoliansky } \\
\text { et al. [19] }\end{array}$ & & & & $X$ & & & & \\
\hline An introduction to smart dairy farming & $\begin{array}{l}\text { Provide insights for } \\
\text { smart dairy farming }\end{array}$ & $\begin{array}{l}\text { Lokhorst } \\
{[20]}\end{array}$ & $x$ & $X$ & $X$ & $X$ & $X$ & $X$ & $X$ & $X$ \\
\hline $\begin{array}{l}\text { The O3-Farm project: First evaluation of } \\
\text { a business process management (BPM) } \\
\text { approach through the development of } \\
\text { an experimental farm management } \\
\text { system for milk traceability }\end{array}$ & $\begin{array}{l}\text { Develop a FMIS for } \\
\text { milk traceability }\end{array}$ & $\begin{array}{l}\text { Zaninelli } \\
\text { and Pace } \\
\text { [21] }\end{array}$ & & & $X$ & & & & & \\
\hline
\end{tabular}


Table 5. Cont.

\begin{tabular}{|c|c|c|c|c|c|c|c|c|c|c|}
\hline \multirow{2}{*}{ Study Title } & \multirow{2}{*}{ Objective } & \multirow{2}{*}{$\begin{array}{l}\text { Authors } \\
\text { and Year }\end{array}$} & \multicolumn{8}{|c|}{ Field of Focus } \\
\hline & & & F1 & F2 & F3 & F4 & F5 & F6 & F7 & F8 \\
\hline $\begin{array}{l}\text { Farming for the future towards better } \\
\text { information-based decision-making and } \\
\text { communication }\end{array}$ & $\begin{array}{l}\text { Compile a list of } \\
\text { FMISs in New } \\
\text { Zealand }\end{array}$ & $\begin{array}{l}\text { Allen and } \\
\text { Wolfert } \\
\text { [22] }\end{array}$ & $X$ & $X$ & $x$ & $X$ & $X$ & $x$ & $X$ & $X$ \\
\hline $\begin{array}{c}\text { Agricultural information systems and } \\
\text { communication networks: the case of } \\
\text { dairy farmers in the Samsun province } \\
\text { of Turkey. }\end{array}$ & $\begin{array}{l}\text { Analyze the current } \\
\text { information } \\
\text { systems used by } \\
\text { dairy farmers } \\
\text { Analyze the }\end{array}$ & $\begin{array}{l}\text { Demiryurek } \\
\text { et al. [23] }\end{array}$ & $X$ & & & & & & & \\
\hline $\begin{array}{l}\text { Adoption of computer-based } \\
\text { information systems: The case of dairy } \\
\text { farmers in Canterbury, NZ, and } \\
\text { Florida, Uruguay. }\end{array}$ & $\begin{array}{l}\text { adoption of } \\
\text { information } \\
\text { systems in New } \\
\text { Zealand and } \\
\text { Uruguay }\end{array}$ & $\begin{array}{l}\text { Alvarez } \\
\text { and } \\
\text { Nuthall } \\
\text { [24] }\end{array}$ & $X$ & & & $X$ & & & & \\
\hline $\begin{array}{l}\text { Data standards used for data-exchange } \\
\text { of FMIS (44); A research carried out } \\
\text { within the Dutch Program on } \\
\text { Precision Agriculture. }\end{array}$ & $\begin{array}{l}\text { Evaluate the data } \\
\text { standards used for } \\
\text { data exchange in } \\
\text { FMISs }\end{array}$ & $\begin{array}{l}\text { Robbemond } \\
\text { and } \\
\text { Kruize } \\
\text { [25] }\end{array}$ & $X$ & & & & & & & \\
\hline $\begin{array}{l}\text { Phosphorus budget and land use } \\
\text { relationships for the Lake Okeechobee } \\
\text { Watershed, Florida }\end{array}$ & $\begin{array}{l}\text { Understand the } \\
\text { current imports and } \\
\text { exports of fertilizers } \\
\text { in the watershed }\end{array}$ & $\begin{array}{l}\text { He et al. } \\
\text { [26] }\end{array}$ & & $X$ & & & $x$ & & & \\
\hline $\begin{array}{l}\text { Performance assessment of food safety } \\
\text { management systems in animal-based } \\
\text { food companies in view of their context } \\
\text { characteristics: A European study }\end{array}$ & $\begin{array}{l}\text { Assess food safety } \\
\text { management } \\
\text { systems in } \\
\text { animal-based food } \\
\text { companies }\end{array}$ & $\begin{array}{l}\text { Luning } \\
\text { et al. [27] }\end{array}$ & & & & & $X$ & & & \\
\hline $\begin{array}{l}\text { Spatial and temporal activity of cattle } \\
\text { grazing in Mediterranean oak woodland }\end{array}$ & $\begin{array}{l}\text { Examine the } \\
\text { foraging behavior } \\
\text { of cattle }\end{array}$ & $\begin{array}{l}\text { Schoenbaum } \\
\text { et al. [28] }\end{array}$ & & & & $X$ & & & & \\
\hline \multirow[t]{2}{*}{$\begin{array}{l}\text { A cloud-based farm management } \\
\text { system: Architecture and } \\
\text { implementation }\end{array}$} & $\begin{array}{l}\text { Design of a } \\
\text { cloud-based FMIS }\end{array}$ & $\begin{array}{l}\text { Kaloxylos } \\
\text { et al. [29] }\end{array}$ & $X$ & & & & & & & \\
\hline & & Total & 6 & 6 & 4 & 7 & 5 & 3 & 3 & 2 \\
\hline
\end{tabular}

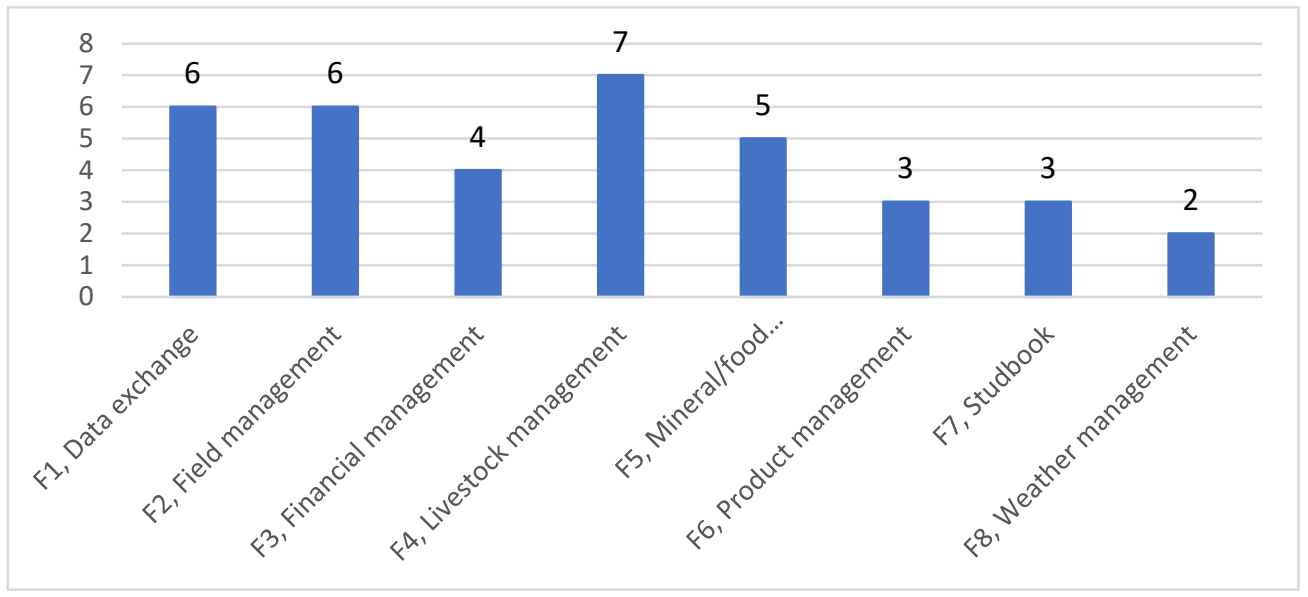

Figure 6. The number of reviewed papers that concern a certain field of focus of an FMIS.

\subsection{Features of FMISs}

This section answers RQ2, which is about the features of FMISs used in dairy farming. The different features of FMISs in the dairy sector were discovered via the MLR and the survey. The features of the FMISs were analyzed using the websites of the FMISs. A feature diagram was considered the best way of visualizing the results of research question 2, which is shown in Figure 7. In this feature model, it is shown if a certain feature is mandatory for a dairy FMIS or optional. Furthermore, all of the abstract features are split into concrete "subfeatures" to create a clear overview of features. 


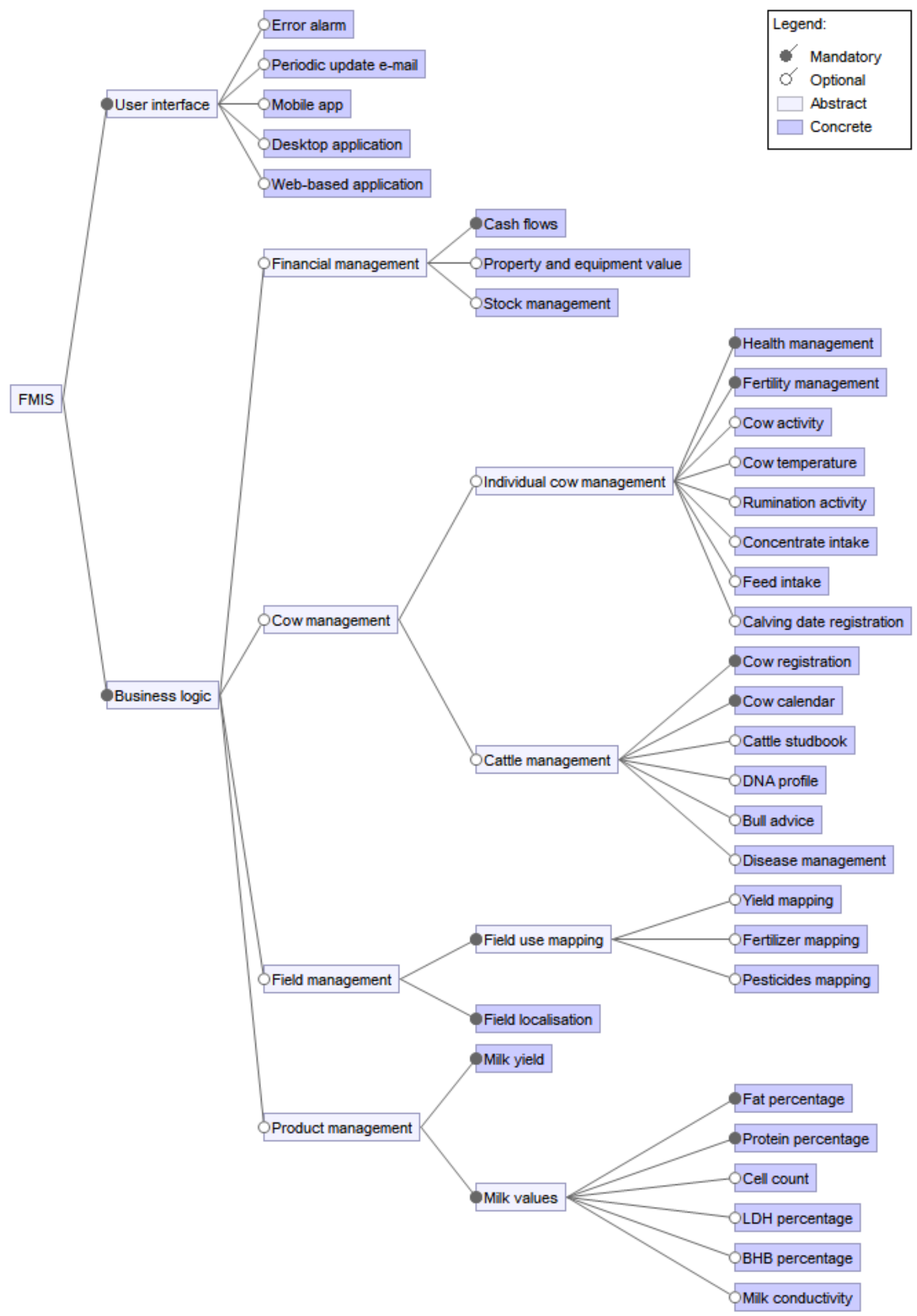

Figure 7. The feature model of FMISs in the Dutch dairy sector.

As shown in this figure, FMIS systems collect and combine many types of data: fertility values, cow activity, rumination activity, concentrate feed intake, calving dates, 
milk yield, milk values (fat percentage, protein percentage, cell count, LDH percentage, $\mathrm{BHB}$ percentage, conductivity), fertilizer use, field location, field area, bull characteristics, feed intake, and money flows.

\subsection{Advantages and Disadvantages of FMISs}

This section answers RQ3, which is about the advantages and disadvantages of the current FMISs used in dairy farming. The advantages of the current FMIS, as mentioned by the farmers, are given as follows:

- $\quad$ The FMIS provides easy and clear access to useful data.

- $\quad$ The FMIS works 24/7; it can provide data at any time.

- $\quad$ The FMIS offers the farmer a way to react quickly to certain situations.

- $\quad$ The data of the FMIS is easy to be exported to other systems.

The most mentioned advantage of the FMIS was the fact that it provides easy and clear access to useful data, as shown in Figure 8.

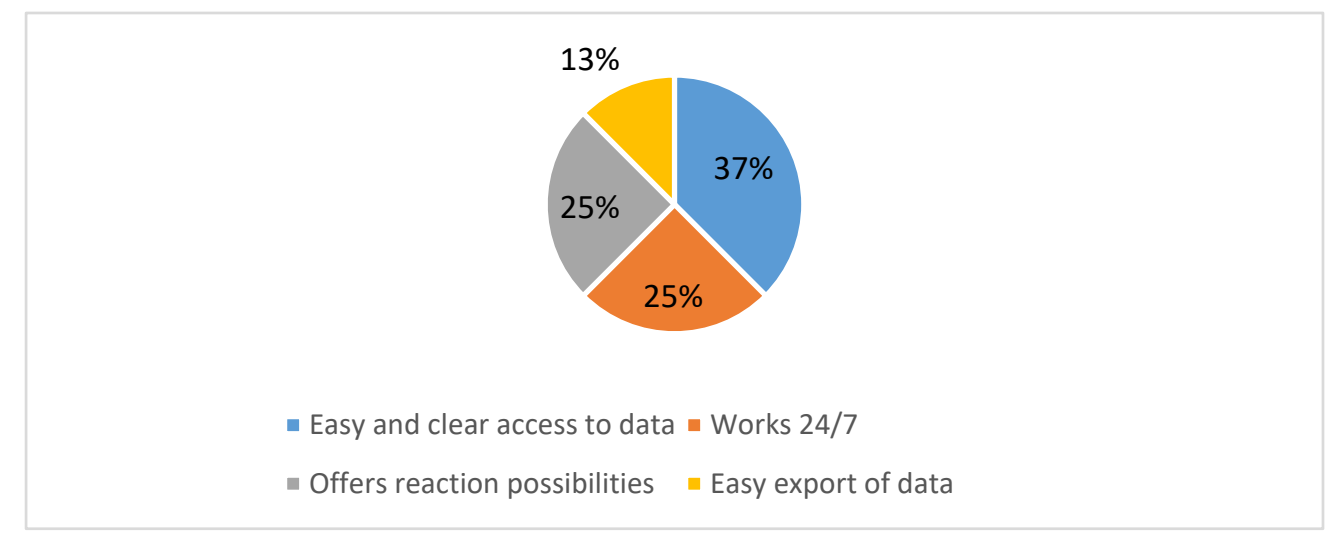

Figure 8. The advantages of the current FMIS.

The disadvantages of the current FMIS, as mentioned by the farmers, are listed as follows:

- $\quad$ The current FMIS or extra options are too expensive.

- $\quad$ A new FMIS is not much better than an FMIS the farmer is currently using.

- A new FMIS will not be used by the farmer.

- The FMIS offers an unclear display of the data.

- $\quad$ The FMIS does not contain useful overviews the farmer wants to see.

The disadvantages that were most mentioned is the fact that a new FMIS is not better than one that is currently used by the farmer, and the costs of an FMIS, as shown in Figure 9. This figure clearly shows that the costs of an FMIS are very important for the farmers.

The advantages and disadvantages of the current FMIS should be taken into account when developing or improving the FMIS. The farmers often mention particularly the high investment costs of deploying an FMIS or extra options for the FMIS they have already deployed. Moreover, the survey asked why farmers do not use certain FMISs. Apart from high investment costs, another argument that was often mentioned is that farmers already use a similar product and do not want to migrate to a new system. When developing a new FMIS, developers should consider whether very similar products already exist because farmers who already purchased a similar product will be reluctant to buy a new one. 


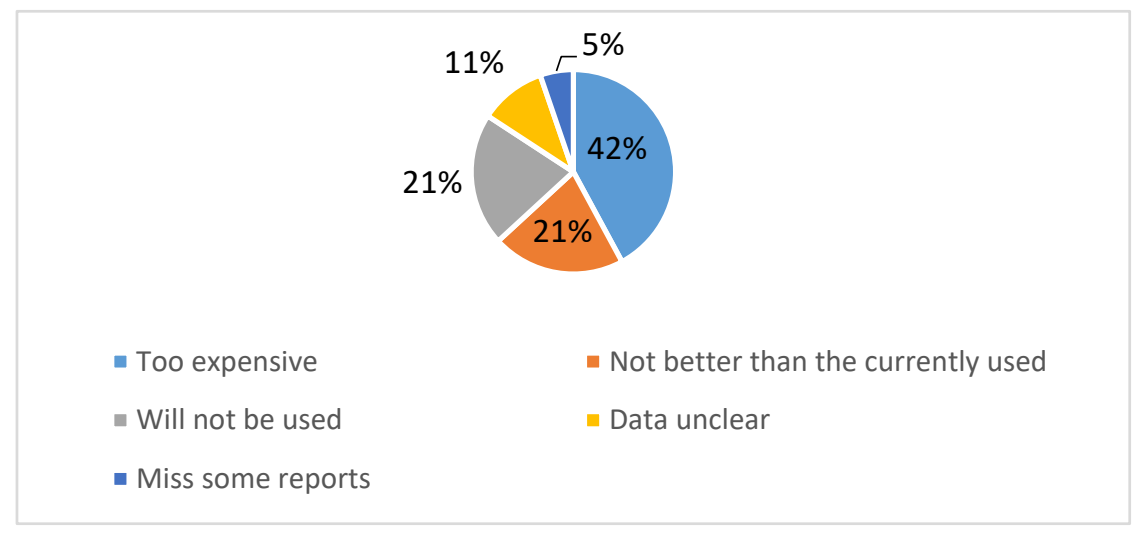

Figure 9. The disadvantages of the current FMIS.

\subsection{Missing Features}

This section answers RQ4, which is about the features the farmers miss in the current FMISs used in dairy farming. The RQ is answered using the survey responses. The responses show that the farmers were generally satisfied with the FMIS they use. However, some recommendations were also suggested. Some farmers stated some of the features that they missed, of which the prominent are:

- To operate and control the machine fully in order to gather all the data from the FMIS;

- $\quad$ To process other types of data in the FMIS;

- To export data from an FMIS to another management system used by the farmer;

- $\quad$ To generate certain overviews of the data.

The missing feature that was mentioned most is the lack of options to operate and control the machines used at farm fully in order to gather all the required data. Figure 10 shows the distribution of missing features.

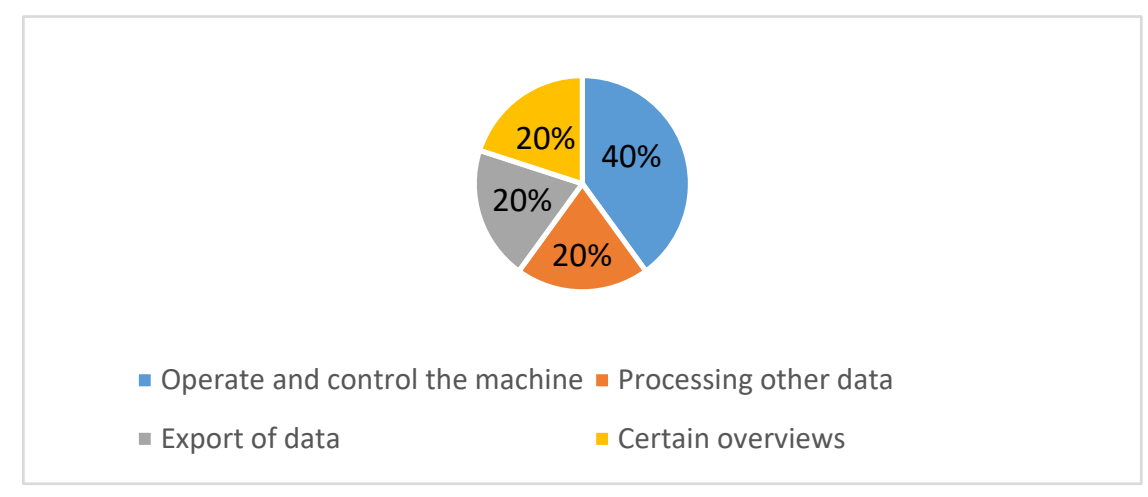

Figure 10. Missing features of the current FMIS.

The answer to RQ4 also resulted in a similar conclusion to the answers to RQ3. The farmers want to all of the diverse kinds of data that are available to them. However, when combining many different types of data from different systems, the integration and presentation of the data is challenging. The farmers find it easier to use only one FMIS system that integrated all of the data for the entire farm and not a fragmented set of FMISs.

\subsection{Data Management in FMISs}

This section answers RQ5, which is about the kinds of data that are collected and managed by FMISs used in dairy farming. 


\subsubsection{Survey Results}

Diverse kinds of data are collected and integrated by different FMISs. Different kinds of data are related to different features, as mentioned in RQ2. The FMIS links that currently exist are shown as follows: Lely T4C is linked with CRV Veemanager, and Delaval Herd Manager is linked with Delaval Delpro and CRV Veemanager.

These links contain the following features: PC/mobile app, cow calendar, fertility management, cow activity, disease management, rumination activity, concentrate feed intake, calving date registration, cow registration, milk yield, milk values (fat percentage, protein percentage, cell count, LDH percentage, BHB percentage, and conductivity). When these features are compared to the features mentioned in RQ2, it can be concluded that almost all of the mentioned features in RQ2 are available in one of these FMIS. This means that with only a few additions, a complete FMIS can be built.

\subsubsection{MLR Results}

Many different kinds of data are collected and linked by the FMIS. The collected data are as follows: fertility values, cow activity, rumination activity, concentrate feed intake, calving dates, milk yield, milk values (fat percentage, protein percentage, cell count, LDH percentage, BHB percentage, conductivity, fertilizer use, field location, field area, bull characteristics, feed intake, and money flows.

\section{Discussion}

In order to guarantee the quality and validity of the survey, the online survey questionnaire used in this study was first sent to three farmers, their responses analyzed, and their feedbacks incorporated in the final version of the survey. The added step of feedback ensured that most of the farmers would understand the used terms and asked questions and would provide the right kind of answers. Our knowledge of the dairy sector is such that the average farmer uses more than one FMIS. However, the survey results of this study show that this is not always the case: only 15 out of the 32 farmers use an FMIS and less than a third use two or more FMISs. A possible explanation for this is that most respondents are the so-called hobby farmers. This means that most farmers manage a small farm without it being a primary source of income. Though our survey can be considered as a pilot study, it provided essential information for the overall understanding of FMIS systems used in practice.

In addition, the survey provided a starting point for further research via an MLR. Although the results depend on the opinion of the few farmers who answered the survey, it still provides usable answers. For instance, we were able to identify the advantages and disadvantages of FMISs based on the responses of these farmers and further corroborated the findings using MLR and SLR studies. Although we aimed to reach more farmers using our survey, the number of participants was limited because it is well-known that a large percentage of farmers do not respond to mail surveys [30]. According to the analysis of Pennings et al. [30], some of the farmers expected compensation such as money/gifts/coupons in the Unites States. However, our research did not have any extra budget for such compensations that can be provided to the participants. The time to receive a survey is important for farmers as mentioned in Pennings et al.'s study [30]. Due to the COVID-19 pandemic and the increasing number of COVID-19 cases at national and international levels, the situation is even worse in terms of the number of respondents who is willing to contribute to this type of research. As such, we had a limited number of respondents in this study. We believe that our survey can be considered as a pilot study; however, it provides essential information for the overall understanding of the advantages and disadvantages of the FMIS systems used. As our research concept is remarkably interesting, representative research in this area can be carried out in the future. It might be better to use the questionnaire interview collected in the field research. Such research is difficult and costly to carry out, but it might be possible to collect more material for analysis. If advantages and disadvantages of FMISs are considered when developing or updating an FMIS, the values of the FMISs 
will most likely increase substantially. The same holds true for results related to the other research questions.

For a follow up study, we will consider adding the following research question because it was missing in this study: "How much does the farmer feel the FMIS is important in daily work?" While we received indirect partial responses regarding this issue, it would better if we could ask this question directly.

For a large part of this grey literature search, company websites were used. Company websites are not independent and also have an unknown author. However, these websites are all considered to be objective and trustworthy sources since the websites are mainly used to retrieve product specifications and to snowball towards other FMISs. Finally, since most of the FMISs were developed in the last decade (the companies that developed them are mostly recently established), it can be concluded that the field of FMIS is developing very fast. Therefore, it is possible that within a few years, the results of this research become outdated. However, since the current status of the use of FMISs in the dairy sector was unknown, this research provides useful. Most importantly, this study is important for its methodological approach since it provides an approach on how to derive an overview of the status of an information system using a combination of a survey and the MLR research approach.

One of the disadvantages stated by the farmers is that the current FMISs or the extra options offered are too expensive. FMIS vendors should develop new service types or strategies to increase the number of customers and, thereby, improve affordability and broader adoption. For instance, a large fee can be divided into monthly prices or different product prices can be created based on available features.

\section{Conclusions}

This research showed the benefits of using both scientific literature and grey literature. The use of a survey form to support this search process demonstrated that this approach is effective in increasing the coverage of sources. For the Netherlands, 50 FMISs for dairy farms were retrieved in this research. All of these FMISs have different focus areas and, therefore different features. In this research, 33 different features were found. The current FMISs have their advantages and disadvantages, which are mentioned in the results of research questions 3 and 4. Some of the mentioned FMISs can already be linked together, which results in a very complete, structured overview of the data generated by a farm. We observed that grey literature provides new insights from a practical point of view to systematic reviews.

The main finding is that FMISs support farm management effectively, which translates into lower costs, increased product quality, improved animal welfare, and an overall increase in safety. Another finding in Dutch dairy sector is that there are many different FMISs options and different features exist in these systems. Farmers must be very careful while selecting the FMIS for their farms because some features are only limited to a certain number of FMISs.

As our research concept is unique and has resulted in interesting results, in-depth research covering a more representative sample of the user group should be carried out in the future. Instead of an online survey, it would be better to use questionnaire interviews in the field involving more respondents. Such research is difficult and costly to carry out, but it will provide detailed information for analysis.

Another potential future work is to investigate the features of FMIS with respect to cognitive technologies such as machine learning, computer vision and natural language processing. Since artificial intelligence (AI) technologies, particularly machine learning and deep learning, have been applied successfully in precision agriculture, new research using cognitive technologies can be carried out in this field. Several studies have discussed the use of cognitive technologies and artificial intelligence in organizations [31-34]. While previous FMISs used different math equations for data analytics purposes, recent FMISs have started to apply machine learning technology for data analytics. A subcategory of 
machine learning called deep learning has been recently applied in precision agriculture successfully. In a recent SLR paper, we have described how machine learning has been applied to improve dairy farm management [35]. However, the potential application areas of $\mathrm{AI}$ in dairy farm management have been barely explored.

Author Contributions: Conceptualization, A.K. and C.C.; data curation, R.B.; formal analysis, A.K., R.B. and C.C. funding acquisition, A.M. investigation, A.K, R.B., C.C., A.M. methodology, A.K., R.B. and C.C. resources, A.K. supervision, A.K. and C.C. validation, A.K., R.B. and C.C. visualization, R.B. writing-original draft, A.K., R.B., C.C. writing-review and editing, A.K., R.B., C.C. and A.M. All authors have read and agreed to the published version of the manuscript.

Funding: Authors thanks to the Molde University College-Specialized Univ. in Logistics, Norway for the support of Open access fund.

Data Availability Statement: Not applicable.

Acknowledgments: Authors thanks to the Wageningen University \& Research, The Netherlands for the infrastructure support.

Conflicts of Interest: The authors declare no conflict of interest.

\section{Appendix A}

\section{Survey Questions}

1. Do you use one or more FMISs on your farm? If not, then proceed with question 7.

- Yes

- No

2. Which FMISs do you use?

3. Which data do these FMISs collect?

4. What are the advantages and disadvantages of the FMIS you are using?

5. What are the different features of the FMIS you are using?

6. Do you lack a feature on the FMIS you are using, if so which feature(s)?

7. Have you heard of other FMIS? If not, the question is over.

- Yes

- $\quad$ No

8. Which FMISs do you know?

9. Which data do these FMISs collect?

10. Why are you not using this FMIS?

\section{References}

1. Lewis, T. Evolution of farm management information systems. Comput. Electron. Agric. 1998, 19, 233-248. [CrossRef]

2. Fountas, S.; Carli, G.; Sørensen, C.; Tsiropoulos, Z.; Cavalaris, C.; Vatsanidou, A.; Liakos, B.; Canavari, M.; Wiebensohn, J.; Tisserye, B. Farm management information systems: Current situation and future perspectives. Comput. Electron. Agric. 2015, 115, 40-50. [CrossRef]

3. Tummers, J.; Kassahun, A.; Tekinerdogan, B. Obstacles and features of Farm Management Information Systems: A systematic literature review. Comput. Electron. Agric. 2019, 157, 189-204. [CrossRef]

4. O'Grady, M.J.; O'Hare, G.M.P. Modelling the smart farm. Inf. Processing Agric. 2017, 4, 179-187. [CrossRef]

5. Abioye, A.E.; Abidin, M.S.Z.; Mahmud, M.S.A.; Buyamin, S.; Ishak, M.H.I.; Rahman, M.K.I.A.; Otuoze, A.O.; Onotu, P.; Ramli, M.S.A. A review on monitoring and advanced control strategies for precision irrigation. Comput. Electron. Agric. 2020, 173,105441 [CrossRef]

6. Hogeveen, H.; Ouweltjes, W.; de Koning, C.; Stelwagen, K. Milking interval, milk production and milk flow-rate in an automatic milking system. Livest. Prod. Sci. 2001, 72, 157-167. [CrossRef]

7. Eckelkamp, E.A.; Bewley, J.M. On-farm use of disease alerts generated by precision dairy technology. J. Dairy Sci. 2020, 103, 1566-1582. [CrossRef] [PubMed]

8. Garousi, V.; Felderer, M.; Mäntylä, M.V. Guidelines for including grey literature and conducting multivocal literature reviews in software engineering. Inf. Softw. Technol. 2018, 106, 101-121. [CrossRef]

9. Pfleeger, S.L.; Kitchenham, B.A. Principles of survey research: Part 1: Turning lemons into lemonade. ACM SIGSOFT Softw. Eng. Notes 2001, 26, 16-18. [CrossRef] 
10. Kitchenham, B.; Brereton, O.P.; Budgen, D.; Turner, M.; Bailey, J.; Linkman, S. Systematic literature reviews in software engineering-A systematic literature review. Inf. Softw. Technol. 2009, 51, 7-15. [CrossRef]

11. Asemi, A.; Safari, A.; Zavareh, A.A. The role of management information system (MIS) and Decision support system (DSS) for manager's decision making process. Int. J. Bus. Manag. 2011, 6, 164-173. [CrossRef]

12. Schöpfel, J.; Farace, D.J. Grey literature. In Encyclopedia of Library and Information Sciences, 3rd ed.; CRC Press: Boca Raton, FL, USA, 2010; pp. 2029-2039.

13. Jalali, S.; Wohlin, C. Systematic literature studies: Database searches vs. backward snowballing. In Proceedings of the ACMIEEE International Symposium on Empirical Software Engineering and Measurement; Lund, Sweden, 20-21 September 2012, IEEE: Piscataway, NJ, USA, 2012; pp. 29-38.

14. Van Selm, M.; Jankowski, N.W. Conducting Online Surveys. Qual. Quant. 2006, 40, 435-456. [CrossRef]

15. Fu, W.; Tunney, H.; Zhang, C. Spatial variation of soil nutrients in a dairy farm and its implications for site-specific fertilizer application. Soil Tillage Res. 2010, 106, 185-193. [CrossRef]

16. Orr, R.; Tozer, K.N.; Griffith, B.A.; Champion, R.A.; Cook, J.E.; Rutter, M. Foraging paths through vegetation patches for beef cattle in semi-natural pastures. Appl. Anim. Behav. Sci. 2012, 141, 1-8. [CrossRef]

17. Phillips, R.; Beeri, O.; Scholljegerdes, E.; Bjergaard, D.; Hendrickson, J. Integration of geospatial and cattle nutrition information to estimate paddock grazing capacity in Northern US prairie. Agric. Syst. 2009, 100, 72-79. [CrossRef]

18. Mugnier, S.; Magne, M.; Pailleux, J.; Poupart, S.; Ingrand, S. Management priorities of livestock farmers: A ranking system to support advice. Livest. Sci. 2012, 144, 181-189. [CrossRef]

19. Spoliansky, R.; Edan, Y.; Parmet, Y.; Halachmi, I. Development of automatic body condition scoring using a low-cost 3-dimensional Kinect camera. J. Dairy Sci. 2016, 99, 7714-7725. [CrossRef]

20. Lokhorst, C. An introduction to smart dairy farming; Hogeschool van Hall Larenstein: Leeuwarden, The Netherlands, 2018.

21. Zaninelli, M.; Pace, M.R. The O3-Farm Project: First Evaluation of a Business Process Management (BPM) Approach through the Development of an Experimental Farm Management System for Milk Traceability. Agriculture 2018, 8, 139. [CrossRef]

22. Allen, J.; Wolfert, J. Farming for the Future: Towards better Information-Based Decision-Making and Communication. Phase I: Australasian Stocktake of Farm Management Tools Used by Farmers and Rural Professionals. Available online: https:/ / edepot. wur.nl/194811 (accessed on 2 June 2021).

23. Demiryurek, K.; Erdem, H.; Ceyhan, V.; Atasever, S.; Uysal, O. Agricultural Information Systems and Communication Networks: The Case of Dairy Farmers in the Samsun Province of Turkey. Inf. Res. 2008, 13, 13. Available online: http://www.informationr. net/ir/13-2/paper343.html (accessed on 2 June 2021).

24. Alvarez, J.; Nuthall, P. Adoption of computer based information systems: The case of dairy farmers in Canterbury, NZ, and Florida, Uruguay. Comput. Electron. Agric. 2006, 50, 48-60. [CrossRef]

25. Robbemond, R.; Kruize, J.W. Data Standards Used for Data-Exchange of FMIS (44). 2012. Available online: https:/ / sites.google com/site/agrilabreferences/ (accessed on 19 May 2020).

26. He, Z.; Hiscock, J.G.; Merlin, A.; Hornung, L.; Liu, Y.; Zhang, J. Phosphorus budget and land use relationships for the Lake Okeechobee Watershed, Florida. Ecol. Eng. 2014, 64, 325-336. [CrossRef]

27. Luning, P.; Kirezieva, K.; Hagelaar, G.; Rovira, J.; Uyttendaele, M.; Jacxsens, L. Performance assessment of food safety management systems in animal-based food companies in view of their context characteristics: A European study. Food Control. 2013, 49, 11-22. [CrossRef]

28. Schoenbaum, I.; Kigel, J.; Ungar, E.D.; Dolev, A.; Henkin, Z. Spatial and temporal activity of cattle grazing in Mediterranean oak woodland. Appl. Anim. Behav. Sci. 2017, 187, 45-53. [CrossRef]

29. Kaloxylos, A.; Groumas, A.; Sarris, V.; Katsikas, L.; Magdalinos, P.; Antoniou, E.; Politopoulou, Z.; Wolfert, S.; Brewster, C.; Eigenmann, R.; et al. A cloud-based Farm Management System: Architecture and implementation. Comput. Electron. Agric. 2014, 100, 168-179. [CrossRef]

30. Pennings, J.M.; Irwin, S.H.; Good, D.L. Surveying farmers: A case study. Appl. Econ. Perspect. Policy 2002, 24, 266-277. [CrossRef]

31. Kwilinski, A.; Kuzior, A. Cognitive technologies in the management and formation of directions of the priority development of industrial enterprises. Manag. Syst. Prod. Eng. 2020, 28, 133-138. [CrossRef]

32. Schatten, M.; Đurić, B.O.; Peharda, T. A Cognitive Agent for University Student Support. In Proceedings of the 2021 IEEE Technology \& Engineering Management Conference-Europe (TEMSCON-EUR), IEEE, Dubrovnik, Croatia, 17-20 May 2021; pp. 1-6.

33. Liu, X.; Guo, S. A database construction of S\&T intelligence cognition model. J. Libr. Inf. Sci. Agric. 2021, 33, 32-34.

34. Divyashree, N.; Nandini, P.K. Cognitive Computing Technologies, Products, and Applications. In Evolutionary Computing and Mobile Sustainable Networks; Springer: Singapore, 2021; pp. 693-701.

35. Slob, N.; Catal, C.; Kassahun, A. Application of machine learning to improve dairy farm management: A systematic literature review. Prev. Vet. Med. 2021, 187, 105237. [CrossRef] 